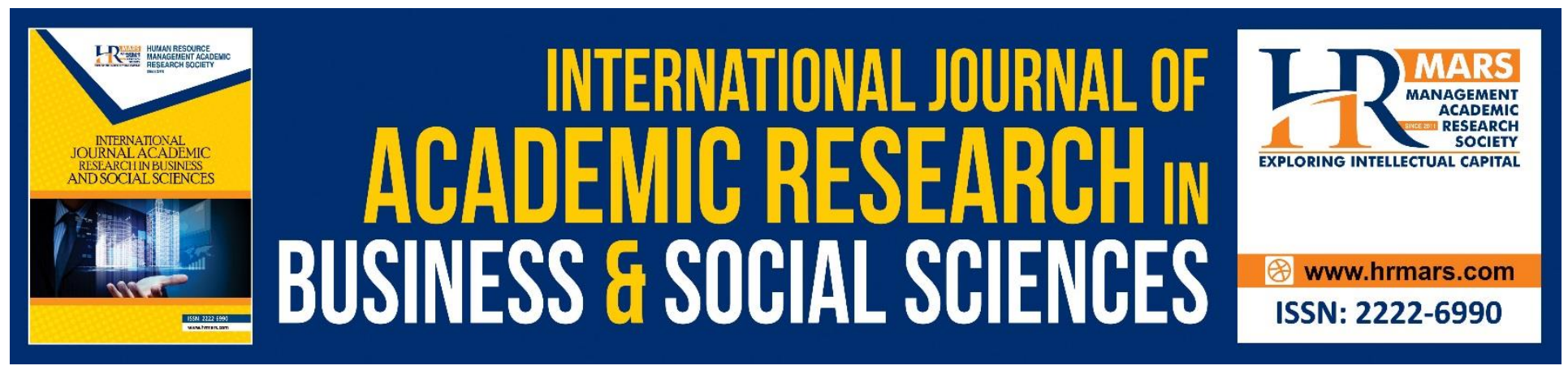

\title{
Iban Dindang and Malay Pantun: Impact on Intellectual Intelligence and Building of Human Capital in Iban and Malay Communities
}

Chemaline Anak Osup, Norjietta Bt Taisin

To Link this Article: http://dx.doi.org/10.6007/IJARBSS/v9-i1/5910

DOI: $10.6007 /$ IJARBSS/v9-i1/5910

Received: 21 Nov 2018, Revised: 10 Dec 2019, Accepted: 01 Jan 2019

Published Online: 27 Jan 2019

In-Text Citation: (Osup \& Taisin, 2019)

To Cite this Article: Osup, C. A., \& Taisin, N. B. (2019). Iban Dindang and Malay Pantun: Impact on Intellectual Intelligence and Building of Human Capital in Iban and Malay Communities. International Journal of Academic Research Business and Social Sciences, 9(1), 1445-1457.

Copyright: (c) 2019 The Author(s)

Published by Human Resource Management Academic Research Society (www.hrmars.com)

This article is published under the Creative Commons Attribution (CC BY 4.0) license. Anyone may reproduce, distribute, translate and create derivative works of this article (for both commercial and non-commercial purposes), subject to full attribution to the original publication and authors. The full terms of this license may be seen

at: http://creativecommons.org/licences/by/4.0/legalcode

Vol. 9, No. 1, 2019, Pg. 1445 - 1457

http://hrmars.com/index.php/pages/detail/IJARBSS

JOURNAL HOMEPAGE

Full Terms \& Conditions of access and use can be found at http://hrmars.com/index.php/pages/detail/publication-ethics 


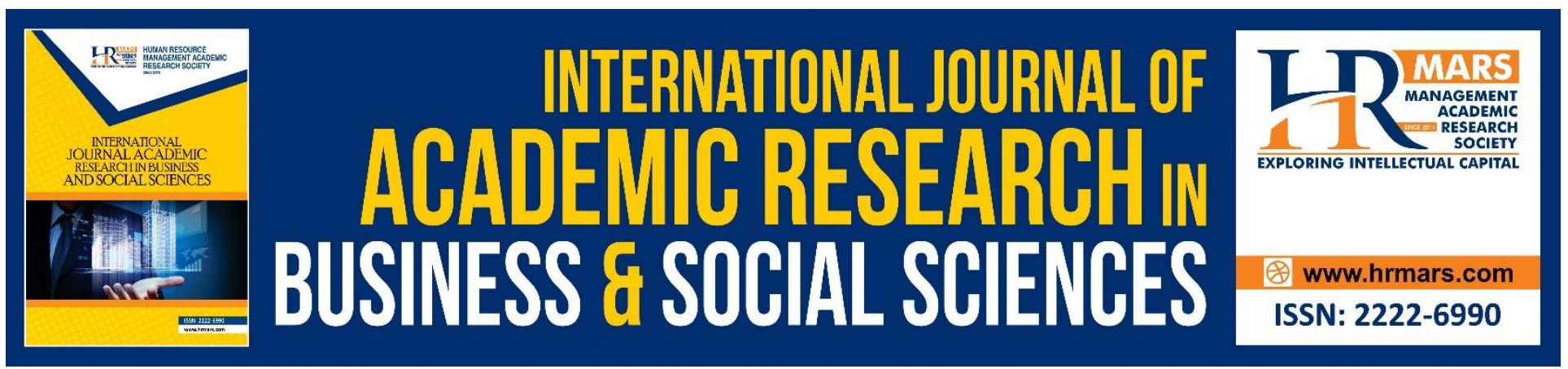

\title{
Iban Dindang and Malay Pantun: Impact on Intellectual Intelligence and Building of Human Capital in Iban and Malay Communities
}

\author{
Chemaline Anak Osup, Norjietta Bt Taisin \\ Faculty of Language and Communication, Universiti Pendidikan Sultan Idris, Malaysia \\ Email: chemaline@fbk.upsi.edu.my,norjietta@fbk.upsi.edu.my
}

\section{Abstract}

This article examines the impact of traditional poems of dindang Iban and Malay pantun on the Iban and Malay society in the aspect of intellectual and human capital development These impacts form a new generation of thoughtful, hardworking, disciplined, insightful, adhering to religious teachings, tolerant, polite and rational so that they may possess noble values of humanity, as well as maintaining the attitude of lifelong learning for prosperity, success and harmony. The objective of this study is achieved because the findings successfully shows the impact of these poems on the intellectual intelligence and human capital development in the Iban and Malay communities. This research adopts the semiotic theory of Richard and Ogden and engages field work and analysis documents. The implication of this study is the wide use of dindang and pantun to enrich human capital with progressive development and attitudes, besides cultivating high ethical and moral values among the members of the ethnic society. Dindang Iban and Malay pantun will remain relevant to the communities concerned because of its communicational function as a tool to convey the intent of the hearts, desire, intention, advice, morality and didactic instructions, and at the same time reflecting on the customs and religious beliefs of the society. The didactic nature of these two poems makes it easy to educate the communities through motivation, advice, satire and convey religious messages for building characters and human capital by filling the minds of people with noble attributes.

Keywords: Intellectual Intelligence, Human Capital, Semiotic, Progressive, Ethical, Didactic, Identity

\section{Introduction}

This article examines the impact of Iban dindang and Malay pantun on the intellectuality and development of human capital in the Iban and Malay communities. Both these traditional poems are the creative works of the Iban and Malays in Malaysia, and can be considered as great literary treasures which are still relevant today. As a genre of literature, Iban dindang has become an important poetry in the Iban community. On the other hand, the Malay community considers pantun 
as a means of communicational expression in their lives, especially from the moral and religious aspects.

These poems record the way of life and the activities of their lives in their communities, and they managed to maintain their resilience, accuracy, relevance and significance in the era of globalization, despite facing strong competition from the development of information technology. Dindang and pantun will always remain relevant throughout the ages because they continue to play an important role in their customs and traditions, reflecting the high and pure Malay and Iban ancestral culture.

The location of the study chosen is a small place known as the Simunjan District under the administration of Samarahan Division in Sarawak. Simunjan is located in between Serian and Sri Aman, which is about $176 \mathrm{~km}$ from Kuching City by road. Most of the people here are Malays and Iban (Mohizah, Julia and Soh, 2006: 19). Census conducted by the Department of Statistics recorded the population of people in Simunjan District. According to the statistics, out of 39,000 people, there are 22,000 Malays, 14,300 Iban and 1,200 Chinese. Simunjan District covers an area of 2,217.67 square kilometers and this region has several important towns under its administration like Gedong, Sebangan and Sebuyau.

Despite the fact that the main occupation of its inhabitants is farming and fishing, there are efforts to develop their regional economy, so Simunjan will not be left behind in the current economic and infrastructure development.

\section{Background of Study}

Iban dindang in Sarawak are included in the traditional poetry called leka main. Leka main means 'seed' (Bruggeman, 1987: 99) but it also means 'words' or 'word' which can be used to create song lyrics, poems and utterances. Leka in Iban language does not mean negligence, delay or being absorbed by something (Dictionary of Language Malay, 1987: 243). On the other hand, the meaning of main in Iban is not only to do something for fun or for relaxing but its meaning also includes all forms of poetry spoken for entertainment and ritual purposes (Richards, 1981: 68). Therefore leka main is not a simple plaything but a poem of the Iban tribal people. As such, leka main is not a matter of play but a form of speech or poem that comes from imagination, creativity and cultural reality of those who have aesthetics, themes and forms which are unique and distinctive.

Some examples of Iban poetry or leka main are dindang, sanggai, dungai, sugi, renong, ramban, entelah, pelandai karung, ensera, jawang, ganu, pantun, ai ansah, geliga, tanya indu, muka kuta, kujuk panggang, sabak, sampi, timang, pengap and et cetera. This traditional Iban folk poetry is a fascinating and beautiful expression in terms of sound, rhythm, diction, stress and recurrence. However, leka main was born in Iban society which believes in animism, and the Iban are heavily influenced by environmental elements. This poetry is then expanded widely since the existence of Iban society, as a cultural heritage of the society so high in value.

In the Malay society, pantun is the oldest poem created, possessed and cherished. It can be said that pantun is a native creation of the Malays, not something adapted from any poetry from other cultures (Piah, 1989: 122). Pantun is always associated with nature because the traditional Malay community often interacts with the natural world around them either in the sea, in the forest, 
in the fields and on the mountains. These elements of nature are adapted as analologies and symbols in pantun and they functioned as illustrations for teaching of moral instructions and religious advice. Apparently, pantun works in almost every activity of the Malay community (Ahmad, 1993: 114). That's why there are various types of pantun that have certain themes like love, praise, advice, religion, custom, art and others, inserted with background of nature.

Dindang and pantun are still popular when viewed based on their use and appreciation today. According to Piah (1989: 14), pantun is a poem with aesthetic and contain various themes and issues. Aesthetics elements in dindang and pantun are used as symbols to reflect the views of its composers. Generally, both poems touch almost all aspects of the lives of the Iban and Malays. In fact, these poems are used as a tool for celebrating certain occasions, carry our special ceremonies related to their customs and traditions, expressing their wishes, imagining their intentions, flowering their speeches, used in the opening words or remarks, used in talks and sayings, to express longing and so on.

These two classic works (dindang and pantun) do not just have their aesthetic value, but they have implied meaning for the purpose of educating their respective communities. As a society's heritage, dindang and pantun need to be preserved and uplifted or raised as a culture and national literature. In addition to that, the Iban community can be identified by the dindang just as well as the Malays by the pantun they have. We need to realize that these poems are not only our ancestral heritage but a tool for us to communicate and to convey the intent of our heart's desires. Therefore, it can be said that dindang and pantun are able to entertain, educate and test the sharpness of our reasoning as well as refine our personal feelings.

\section{Statement of Problem}

Iban communities sometimes call leka main (poetry of Iban people) as pantun because of its metrical properties. Hence, many people are confused by the name pantun, that is, one of the genres of poetry in the corpus of the oral tradition of the Iban community. However, what is called pantun in the Iban literature differs completely from the Malay pantun. Though leka main is lined up and somewhat parallel to pantun, it is not tied to a convention or a sketch which is divided into certain functions or bytes. This feature or character is very significant in traditional Malay pantun.

In the Malay pantun, there is an array which contains two, four, eight, ten or twelve lines. In the poetry the Iban people (leka main), only dindang has the conventions like this Malay pantun. Other traditional Iban poems do not have this particular literary convention. Hence, the lack of exposure in terms of traditional Iban poetry forms make people think that it is the same with the Malay pantun. What is called pantun in Iban has no structure like the Malay pantun. Its form is long. In fact, an Iban pantun can be made of fifty and hundreds of lines. Although usually one line is built between eight up to twelve syllables, the Iban pantun appears to have been deliberately constructed so as to make it easy for readers to grasp its meaning. Listeners or readers will understand the whole the meaning of Iban pantun after he finished reading one string of pantun. 
Importantly, the difference between Iban pantun and Malay pantun is the number of rows and the length of the pantun. Clearly, the basic form of Malay pantun consists of four lines and the Iban pantun consist hundreds of rows or lines that are parallel. Therefore, the only genre of Iban poetry which is similar to Malay pantun is the dindang. The similarity of these two poems is from the aspect of their line, the number of rows in the byte, the number of syllables in each row, clues, functions and values.

Lack of documentation on traditional Iban poetry cause other people to be confused about it. Therefore, this article is written to show such similarities in terms of the characteristics and functions of both poems including the benefits of moral value and its impact on the intellectual integrity and the building of human capital in the indigenous communities of the Iban and Malays in Sarawak.

\section{Research Objective}

This article has only one objective, that is, to show the impact dindang dan pantun on the intellectual intelligence and the building of human capital in the Iban and Malay communities. This impact will be seen through several aspects in both traditional poems such as verballinguistic elements, logic-mathematics, art and music appreciation, lifelong learning, knowledge exploration, intellectual capital enrichment, culture of progressive attitudes, high moral values, quality improvement in all matters and activities, professionalism enhancement, entrepreneurial skills development, economy, increased understanding and appreciation of religion, collaboration and smart partnership, openness of mind, patriotism, prioritizing national unity and the well-being of life.

\section{Significance}

Dindang Iban and Malay pantun are important because each of these poems express thoughtful ideas that are delivered in the form of light and easy lines. The significance of dindang and pantun are seen through their deep and meaningful message, namely reflecting the impact on intellectual and human capital development in the Iban and Malay communities. These poems also reflect the lifestyle of the two tribes of peoples. Both dindang and pantun emphasize moral values, practice of language, politeness, emotional and moral order. These poems are also full of religious teaching, including criticisms, prohibitions, restrictions and warnings, delivered in a gentle and effective way, so that members of the communities will keep away from the wrong things, wrongdoings and the lustiness of the heart which may harm themselves.

It is hoped that this article can highlight the value of humanity, good practice, manners and integrity and moral order, which can be used as a guide to the both communities. Through dindang and pantun, the Iban and Malay community, members are reminded that the ability to control lifestyles and ethos of good communication with each other. Therefore, dindang and pantun are able to generate "cultured" Iban and Malay communities in general (Taslim, 2007: 83) . 


\section{Limitations}

This article is focused on the poems of Iban dindang and Malay pantun only and no others. This is because both dindang and pantun contain four lines that are somewhat parallel. In their metrical properties, lines one and two are part of the clues, while lines three and four are the answer (intentions) to the clues. This study has been carried out in particular to analyse the impact of the two traditional poems on the intellectual and human capital development among the Iban and Malay communities in the Simunjan District in Sarawak (East Malaysia).

By looking at this impact, the researcher is also examining the humanitarian values displayed in both types of poems. But the difference between Iban dindang and Malay pantun will not be discussed here because the focus is on their impact on intellectual intelligence and development of human capital development among the Iban and Malay communities.

\section{Literature Review}

Dindang is a kind of Iban traditional poem in Sarawak. It is an oral poetry in the corpus of oral tradition called leka main (Osup, 2006:17). As a form of poetry, it is a form of utterances that comes from one's imagination, his creativity and his cultural realities that have their aesthetics, themes and forms. Pantun is a kind of traditional Malay poem that retains its originality and authenticity. This poem is widely used and can be said to be the most popular poem in the Malay community up to now, which captures the attention of local and oversea researchers overseas. Initially, the Malay pantun was an oral literature but now it has been written as a creative work of a person (Saga, 2005: $\mathrm{x} 1$ ). Generally, Malay pantun is called by various names. For example, in a Javanese language, this poem is known as parikan, and in the Sundanese language it is known as paparikan. In Nusantara, there are various terms or names of pantun, namely panto, teon, matuntun, atuntun, tonton and tuntun or ende-ende (Saludin, 2007: 23-24).

Whether Iban or Malay poetry, poems of four lines have a rhyming pattern of $a-b-a-b$ and is a regular utterance. Based on both internal and external aspects (visual structure), Iban dindang and Malay pantun included certain themes (Piah, 1989: 63). As the oldest poem (Za'ba, 1965: 219) in Malaysia, pantun is a native creation of the Malays who are imitated by Iban people (seen from Malay pantun skemata). The Malay pantun is the original poetry of which is owned by the Malay community (Piah, 1989: 122).

Inside pantun and dindang, both symbolism and analogy serve as a source of moral teaching, messages, mandate, general advice, moral values and humantitarian attributes which show the life ethics of the Iban and Maly communities (Ahmad, 1993: 114). From the historical point of view, the Malays have created a pantun by using the word like or as (Za'ba, 1965: 219). In the Iban community, the dindang is created using the term sempama (in Malay it is called perumpamaan or parable). This is seen in the lines of clues (hints) and answer (intentions).

Iban dindang and Malay pantun are works of national literature. Traditional poetry itself is imaginative and the language is also connotative. Due to the use of metaphors and symbols 
that make the poems beautiful, impressive and is effective for describing something or a phenomenon. These two poems combine sound harmony, rhythm, words that liven up the imaginations, memory and overflow of emotions by using rhyme and figurative words. The inventors of dindang and pantun create the poems in many ways, for example by adding visual form (typography, byte order), sound (rhyme, asonance, alliteration, symbol and orchestration) and selection of words (diction, language metaphorical, rhetorical advice, grammatical elements and language styles).

Piah (1989: 19) mentions the vast use of nature in poetry. Certainly, the use of nature in Iban dindang and Malay pantun has been compressed to show reality and events in lives, neatly arranged in a poetry space that is so small. There is no waste in choosing dictions for creating pantun (Barker, 2004: 47). These forms of poetry have been created in the context of a very important traditional culture, language politeness and communication order (Taslim, 2003: 81-84). These use of language deliver the wishes or intentions of the inventor of the poems. Direct and wrong choice of diction may can crush the feelings of the listener, make him fainthearted, or cause antagonism in society. This is because the Iban and the Malays sometimes consider direct words of rebuke as abusive and uncivilized. In short, dindang and pantun are able to produce a balanced human being and always overseeing action and emotion as well as being able to resist lust (Taslim, 2003: 81 - 84).

Moral and pure values are embedded in these two forms of traditional poems. The moral values embedded in these poems can be a measure of identity (Bagus, 2002: 39) among Malays and Iban, However, the style of speech in dindang and pantun is not too formal in grammar but the words are used in the various contexts or situations (Dictionary of the Fourth Edition Board, 2005: 893) or for certain purpose (Linguistic Dictionary, 1997: 145). Thus, Iban dindang and Malay pantun should be seen as a cultural artifact (Osman, 1996: 2) which reflect the minds and cultures of the Iban and Malay communities.

\section{Methodology}

Fieldwork has been done by implementing two research methods, that is, spontaneous interview utilizing checklist and observation (without involvement) by attending pantun and dindang session and also by document analysis. Through spontaneous conversation the researcher reviews, assesses and explores to analyse the issues about Iban dindang and Malay pantun. Informants share their knowledge about the forms. features, values, themes and function of dindang and pantun. In this context, the researcher conducts qualitative methods because the use of this approach is believed to be able to uncover the views of informants about issues regarding these two poems. This method is considered more appropriate as it takes into account the views of people who are interested in Iban dindang and Malay pantun. The researcher himself as instrument or researcheras-instrument provides partial-speech interview questions as a technique of collecting data.

The method of document analysis is utilized because this approach uses materials such as reference books, dissertations, journals, scientific exercises, books, magazines and other relevant documents for the purpose of obtaining information about the Iban dindang and the Malay 
pantun. For this purpose, researcher visited several libraries in Sarawak such as Sarawak State Library, UiTM Library, UNIMAS Library and Resource Center of the Sarawak State Education Department. The sought-after references include Malay books on pantun, either written by local or foreign scholars (including Indonesia, Brunei and Singapore).

The researcher utilizes Ogden and Richards Semiotic Triangle Theory (1949) which describes the ideas through symbols, by which he expresses meaning and specific significance of the poems. In the context of linguistics, this theory focuses on the symbolism in the text, the built-in language in the sentence structure which contains signs in the language. The language itself is a functional sign system through an operational code that produces the meanings (Sikana, 2005: 34) using semiotic theory (Peirce, 91: 1839-1914). Literature and linguistic texts can be considered as semiotic text.

Based on this semiotic theory, one lexical or word (term) can be broken down into three elements, namely the word (symbol), reference (object or things) and concept (mind). These elements are called entities or symbols. The concept has a direct relationship with the word form (symbols / symbols) and references (objects or references / references). Word (symbol) also has an indirect relationship with reference (thing / matter). Dindang and pantun are best studied with this semiotic triangle theory. This covers language studies primarily sign, symbol and visual design which focuses on three aspects namely icons, indexes and symbols.

The three objectives of the study can be achieved by using semiotic theory as this theoretical framework can provoke the mind to understand dindang and pantun. The "mind" is actually the concept that is described through symbols. In the context of this study, "symbol" or symbolism refers to the words or diction that are selected, and this utilized the semantic approach to understand it. Then, "reference" in the diagram is a specific item which is referred to for the purpose of interpreting dindang and pantun. So based on the diagram above, concept or mind has direct contact with the other two symbols and references. Symbol refers to the form of words, symbols or references. "References" refer objects or things (Lotsman, 1990). It is clear that the symbols (words, symbols) are related, though indirectly, with "reference" (thing/matter).

\section{Impact of Intellectual Intelligence and the Building of Human Capital}

The findings show that Iban dindang and Malay pantun have an impact on the intellectual intelligence and human capital building in the Iban and Malay communities. The researcher lists thirty-eight aspects or elements of intellectual intelligence and human capital building elements. It then shows the functions of dindang and pantun in most of their life activities (Ahmad, 1993: 114) and this explains why there are various themes of dindang and pantun (Piah, 1989: 63). Discussions about the detailed impact of these poems on the intellectual intelligence and the building of human capital is summarized in the point-form list below:

1) Insightfulness

2) Creative and critical skills

3) Verbal-linguistic skills

4) Logic-mathematics 
5) Spatial use

6) Appreciation of art and music

7) Interpersonal and intrapersonal skills

8) Stimulate lifelong learning

9) Emphasis on the mastery and exploration of knowledge

10) Enriching intellectual capital

11) Nurture progressive attitudes

12) Enriched high ethical and moral values

13) Consistent business planning to produce continuous success

14) Improved quality in all matters and activities of life

15) Enrich the concept of caring society

16) Intentions to build the nation's ability in terms of knowledge, skills and expertise

17) Improve the professionalism and skills of the workforce

18) Increase management capabilities

19) Developing entrepreneurial skills

20) Apply moral, purity and ethical values and nourish spiritual and positive attitudes

21) Increase understanding and appreciation of religion

22) Improve skills in economics

23) Pioneering smart collaboration and sharing with each other

24) Literate \& proficient information technology

25) Doing a paradigm shift and showcasing a high performance work culture

26) Leadership, integrity, transparency and effectiveness

27) Efficient, clean and trustworthy

28) Achieve quality work

29) Improving competence and productivity

30) Ability to create value (value creation) and gain value (value added)

31) Disclosure of mind

32) To contribute to self, family, nation and society

33) Career progress

34) Patriotic

35) Mastering language and communication skills

36) Governments respond to demands and current changes and development

37) Active and committed in work or undertaking

38) Assertive in ational unity and well-being

In addition to these, the Iban and Malay communities are concerned with national unity and prosperity. They are committed to work, to master the language and communication skills, to become patriotic and they emphasize on career advancement as well as practicing openness of mind. Readers and listeners of dindang and pantun can see their reflection of culture and identity, apart from their fineness of courtesy and politeness. There is an attractive and aesthetic style of dindang and pantun, which illustrates how keen the Iban and Malay people have on their culture, for which reasons they to maintain their own language and oral traditions. The cultures of these two 
communities are of great importance as reflected through the poems, for example, they are often cautious with their speech in order not to hurt the feelings of other people - so they speak in parables, idioms, proverbs, sayings, metaphors in dindang and pantun. It means that their culture adopts good manners as seen in the polite words organized in dindang and pantun. They work hard but they do not oppress each other despite the burden of survival (Piah, 1989: 19). it is learnt that they serve one another and they call this good act as a virtue and that particular person who does good to each other is considered virtous.

The inventors of dindang and pantun emphasize on the aesthetic values too. As a branch of philosophy, aesthetics give focus on the beauty of the language. Aesthetics relates to the sensory values (feelings and sentiments) that involves perception and art (result of aesthetic experience). Thus, dindang and pantun are featuring insights, futuristic thinking and far-sighted view about life from natural and environmental aspects, economics, politics, social sciences, education, safety, unity, thinking about customs and beliefs and the future of society because all these are related to harmony and well-being of life. These poems have used verbal-linguistic skills in multiple sets of intelligence and language. Undoubtedly, dindang and pantun have been created for art (art for art) as well as for society (art for the community). Through these poems, the old and the young tend to be fond of each other because the poems enable them to think and communicate in creative, expressive and active language arts.

The impact of these poems on their intellectual intelligence injects the spirit of hardwork, positive in entrepreneurship, optimistic, good working culture, motivated, able to organize ideas, be responsible and be oriented on profit and quality, so that they will continue to be enthusiastic and confident as well as having a clear goal to succeed in any field of work involved. This is because the Iban and Malays want to succeed in their economy in this new millennium. In fact, through the New Economic Policy (NEP), both Iban and Malay societies have been restructured for the purpose of eradicating poverty, and improve their living standards. This paradigm shift is necessary for both the communities to change for good towards progress, development and goodness, but this paradigm requires all individuals involved to have unity of the heart, the unity of mind and the high performance in work culture.

Undoubtedly, there are dindang and pantun that touch on matters of leadership and integrity. This aspect is important because this determines the continuity, existence, peace and prosperity as well as the well-being of the Iban and the Malays. Similarly, there is a message and advice on the recommendations and encouragement of producing quality work. This is because quality work are related to ethical culture and integrity that shape a brilliant work culture. In addition, audiences may be able to see their competitiveness and resilience in work culture. In fact, through these poems, they are urged to improve awareness, commitment and cooperation among them to achieve high quality work as defined by their community organization.

Yet, dindang and pantun do not leave the aspect of patriotism as it is a positive attitude of each community itself, including the pride of achievement. They are very concerned about their 
traditional culture (Taslim, 2003: 81-82) including their own language of mother tongue. Through dindang and pantun they developed various forms of language and metaphorical like proverbs, parables, idioms, bids and proverbs.

\section{Implications and Recommendations}

Obviously both the Iban and Malay communities have developed both traditions (dindang and pantun) well enough. For this reason, these poems are considered as the treasures of their arts and culture inherited from their ancestors. This also explains why many scholars are taking studies on Iban and Malay culture. Certainly, during special occasions such as wedding ceremonies, dindang and pantun are sung, and normally the young and old will come up to dance the joget while dindang or pantun is sung. It is recommended that research on dindang and pantun be further intensified by looking at other aspects, apart from analysing the impact on the intellectual intelligence of the two communities mentioned earlier.

\section{Closing}

Dindang and pantun are two traditional poems that have an impact on the intellectual inteligence and the building of human capital on the Iban and Malay communities in Sarawak. These traditions are insightful and have the verballinguistic potential on the readers or listeners. They show appreciation for art and music, as well as interpersonal and intrapersonal skills. It can be said that the poetry of dindang and pantun can encourage lifelong learning and enrich intellectual capital as well as cultivate progressive attitudes, besides nourishing ethical and high moral values among members of their societies. Through these poems, we can see their consistent business planning to produce continuous success, and effort to improve quality in all matters and activities of everyday life.

Finally, the poetry of dindang and pantun certainly can cultivate the concept of caring society, build the nation's ability in terms of knowledge, skills and expertise, improve professionalism and manpower skills, enhancing management capabilities, develop entrepreneurial skills, and apply pure and ethical values as well nurturing the spiritual and positive attitude among the community members. In addition, these two poems are able to increase understanding and appreciation of religion, and indeed become a motivational tool to inject intense and lively spirit to improve skills in economics including pioneering collaboration and smart sharing among each other through information technology skills. This means that these poems have been successfully encouraging people to make paradigm shifts and showcase high performing work culture and demonstrate leadership, integrity, transparency and effectiveness in performing their duties and responsibilities.

The Iban and Malay communities are somehow "educated" through dindang and pantun, for the practice of efficient, clean and trust management, in order to achieve high quality work and improve competence and productivity. In short, these poems are capable of encouraging people to not only create value and but to add value. The patriotic spirit, career progression, language mastery, communication skills and open minds of the Iban and Malay communities (as reflected in dindang 
INTERNATIONAL JOURNAL OF ACADEMIC RESEARCH IN BUSINESS AND SOCIAL SCIENCES

Vol. 9, No. 1, Jan, 2019, E-ISSN: 2222-6990 @ 2019 HRMARS

and pantun Melayu) can certainly contribute to theie well-being in their families, homes and communities as well as in the state of Sarawak as a whole.

\section{Acknowledgment}

This paper is based on the research project entitled Dindang Iban dan Pantun Melayu : Impak Terhadap Keintelektualan dan Pembinaan Modal Insan Dalam Masyarakat Iban dan Melayu. The authors would like to extend their gratitude to the Research Management and Innovation Centre (RMIC), Sultan Idris Education University, Perak, Malaysia for the University Research Grant (Code 2015-0125-107-01) that helped fund the research.

\section{References}

Ahmad, J. (1993) Kesusasteraan Melayu Tradisional, Kuala Lumpur: Dewan Bahasa dan Pustaka

Ahmad, Z. A. (1965). Ilmu Mengarang Melayu. Kuala Lumpur: Dewan Bahasa dan Pustaka.

Barker. C. (2004). Cultural Studies: Theory and Practice. London: SAGE Publications.

Bruggeman, G. (1985). English-Iban Vocabulary. Kuching: Persatuan Kesusasteraan Sarawak.

Bagus, G. N. (2002). Keberadaan Pantun Bali Masa Kini. Denpasar: Universitas Udayana

Kamus Dewan Edisi Keempat. (2005). Kuala Lumpur: Dewan Bahasa dan Pustaka. Kamus Linguistik. (1997). Kuala Lumpur: Dewan Bahasa dan Pustaka.

Kamus Bahasa Malaysia: Edisi Pelajar. (1987). Kuala Lumpur: Dewan Bahasa \& Pustaka.

Kurik Kundi Merah Saga: Kumpulan Pantun Lisan Melayu (2005). Kuala Lumpur:

Dewan Bahasa dan Pustaka.

Manifestasi Minda Masyarakat, selanggaraan oleh Wan Abdul Kadir Wan Yusoff.

Akademi Pengajian Melayu; Kuala Lumpur.

M. T. (1996). "Pantun Sebagai Pencerminan Minda Melayu”. dlm. "Pantun Dan Psikodinamika

Kelisanan" dlm Dewan Sastera, Kuala Lumpur: Dewan Bahasa dan Pustaka

Mohizah, N. Julia, S. and Soh, W. K. (2006). A Sarawak Gazetteer. Kuala Lumpur: Sarawak

Forestry Department Malaysia and Forest Research Institute Malaysia.

Piah, H. M. (1989). Puisi Melayu Tradisional: Satu Pembicaraan Genre dan Fungsi

Kuala Lumpur: Dewan Bahasa dan Pustaka.

Piah, M. P., Hamid, I., Salleh, S. H., Sham, A. H., Kaeh, A. R. \& Dan Ahmad, J. (2000). Kesusasteraan Melayu Tradisional. Kuala Lumpur: Dewan Bahasa dan Pustaka.

Sikana, M. (2005). Teori Sastera Kontemporari. Bangi: Penerbitan Fajar Bakti Sdn Bhd.

Saludin, M. R. (2007). Seni Berpuisi. Pulau Pinang: Goal Intelligent Publishing.

Ogden and Richards. (1949). Theory of Interpretation. New York: Books for Libraries: Press.

Osup, C. (2006). Leka Main: Bentuk dan Fungsi. Manuskrip PhD. Universiti Sains Malaysia

Peirce, C. S. (1991). Pierce on Signs. America: University of Pennyslavia

Richards. (1981). An Iban-English Dictionary, London: Clarendon Press. 
INTERNATIONAL JOURNAL OF ACADEMIC RESEARCH IN BUSINESS AND SOCIAL SCIENCES Vol. 9, No. 1, Jan, 2019, E-ISSN: 2222-6990 ㄷ 2019 HRMARS

Taslim, N. (2003). “Pantun Dan Psikodinamika Kelisanan” dlm Dewan Sastera, Kuala Lumpur: Dewan Bahasa dan Pustaka

Taslim, N. (2007). Pantun dan Pembudayaan Bangsa. DewanSastera. Ogos: 81-84. Kuala Lumpur: Dewan Bahasa dan Pustaka 